\title{
PSYCHOLOGICAL PROBLEMS IN SPEAKING ENGLISH OF THE STUDENTS OF VOCATIONAL SENIOR HIGH SCHOOL
}

\author{
Mukhtarul Anam, Tantri \\ Mukhtarul4anam@gmail.com,tantri0298@gmail.com \\ English Language Education Department, Faculty of Teacher Training and Education, Universitas Islam \\ Lamongan
}

\begin{abstract}
The purpose of the research is to know the students' psychological problems, and to know the efforts of the students to overcome their psychological problems. The research was conducted in SMKN 1 Lamongan at OTKP. The research is qualitative research. It used an observation and a semi-structured interview as a technique to collect the data. Based on the research, the researcher found that the students felt anxious, shy, fear of making mistakes and the students also got a lack of confidence when they were speaking in front of the class. The efforts to overcome their psychological problems were as follows. The students should have the self-confidence to speak, the student should master many vocabularies, and more practices speaking in English, the teacher should give motivation to the students and encourage a habit and accustom the students to use English.
\end{abstract}

Keywords: Speaking, psychological problems

\section{INTRODUCTION}

Speaking is a crucial part of second language learning and teaching (Kayi, 2006:1). When we talk about speaking, speaking has an important role in our life. Learning to speak is the most important component that students should fulfill when learning a second language because a good speaking skill is a measured by the ability to speak well in the language.

For Indonesian students, English as a second language is difficult to learn. Students usually find difficulties in learning English, especially in speaking. Speaking skill is one of the language skills that are very essential to support further oral communication especially in English, but it is the most difficult skill to develop (Munir, 2018:2).

The difficulty of EFL students in performing English speaking is probably caused by cognitive or psychological factors (Ariyanti, 2016:78). The psychological barrier also hinders the students to improve their speaking ability. The psychological barriers will make them low interest and participation in the class. 
The students usually feel shy and unconfident when speaking in front of their classmates. The students feel that they cannot speak well in English. Moreover, the students' also afraid of being laughed by their friends when practicing speaking in the class.

According to Juhana (2012:101) explained that some psychological factors encountered by the students when speaking are as follows:

\section{Fear of mistakes}

Students' fear of making mistakes in speaking English has been a common issue especially in the EFL context like in Indonesia (Juhana, 2010:101). It is natural for any student during the process of learning to make mistakes (Madaci, 2018:14). Some students are afraid when the teacher will give negative evaluations on them.

\section{Shyness}

Shyness is an emotional thing that many students suffer from at some time when they are required to speak in English class (Juhana, 2010:101).

\section{Anxiety}

Some people are predictably and generally anxious about many things (Brown, 2000,151). Scovel (1978:134) in Brown (2000:151) added that anxiety is associated with feelings of uneasiness, frustration, self-doubt, apprehension, or worry. So, anxiety is one of the problems that can make the student feel uncomfortable when they are practice speaking performance in class.

\section{Lack of confidence}

Lack of confidence is one of the aspects that also influence students in speaking skill. Lacking of confidence is a psychological obstacle in foreign language learning (He, 2015:36).

Some teacher only teach reading and writing in the school. The teacher rare to speak using English, the teacher also rarely tells the students to practice speaking English in the school 
environment. So, it causes the students not accustomed to using English. On the other hand, if the students are not accustomed to speaking in English, they will afraid or anxious when the teacher asks them to practice it in the class or in front of their classmates.

There are some ways and efforts that students and teacher do to overcome the psychological problems. First, is increase self-confidence. Brown (2000:145) claimed that no successful cognitive or affective activity can be carried out without some degree of selfesteem, self-confidence, knowledge of yourself, and belief in your capabilities for that activity.

Second, is master vocabulary, Swary (2014:51) explained that because of mastering English vocabulary was the most important component, so to solve that problems, all of the students have to increase their vocabulary knowledge first.

Third, is practice. This is also supported by Swary (2014:50) said that language was a practice. Swary (2014:50) added that the students should practice their English not only in the class activity but also in the out of the class activity.

Fourth, is giving motivation. Swary (2014:52) that if the students had the big motivation to learn speaking English, to speak up in front of their friends automatically they would be always follow everything which the teacher words in order to make them increase their ability in speaking English.

The last is habitual. According to Swary (2014:56) that the solution to encourage the students to speak English was the teacher should speak it as often as possible. Swary also added that if the teacher shy to speak English, how she could expect the students to overcome their fears about speaking English.

There were many researcher that conducted the same topic, such as Juhana (2012) and Ariyanti (2016).

Then, many students of senior high school have problems in speaking 
English, especially related to psychological problems. Based on the explanation above, the purpose of this research are to know about the student's psychological problems and the effort to overcome the students'psychological problems in speaking.

\section{RESEARCH METHOD}

This research is uses qualitative research. According to Ary (2010:424) said that qualitative inquirer deals with data that are in the form of words or pictures rather than numbers and statistics. Qualitative research uses descriptive to explain the data in the research.

Qualitative is chosen by the researcher because it deals with the phenomenon of students' psychological problems when they are speaking in English.

In this study, the researcher conducts the research at SMKN 1 Lamongan. The subject of the research is the students in the second semester of the tenth grade of SMK Negeri 1 Lamongan at OTKP 1 (Otomasisasi dan Tata Kelola Perkantoran) class in the academic year of 2019/2020. The class consists of 36 students, 10 males, and 26 females as the subjects of this research.

In this research, the researcher uses observation and interview to get the data in the field. The observation is used to observe students' psychological problems when speaking in class. The researcher asks the students to practice speaking English in front of the class. Then, the researcher pays attention and takes notes on the students' attitudes, eye-contact, and volume of the voice when the students are presenting their speaking.

Then, the researcher conducted interview to the participants. The researcher uses a semi-structured interview to collect the data from the participants. The purpose of the interview is used to support the data from observation. The 
researcher interviews the students' about the psychological problems that faced by them when speaking in the class. Further, the researcher also conducted an interview to the English teacher to know about the students' psychological problems in speaking and to know about the efforts to overcome the students 'psychological problems in speaking. The instruments are observation guide and interview guide.

Table 1. Instrument of the Research

\begin{tabular}{|c|c|c|}
\hline No. & Instruments & Aim \\
\hline 1. & $\begin{array}{l}\text { Observation } \\
\text { Guide }\end{array}$ & $\begin{array}{l}\text { - To know about the students' } \\
\text { psychological problems in } \\
\text { speaking }\end{array}$ \\
\hline 2. & $\begin{array}{l}\text { Interview } \\
\text { Guide }\end{array}$ & $\begin{array}{l}\text { Students } \\
\text { - To know about the students' } \\
\text { psychological problems in } \\
\text { speaking } \\
\text { Teacher } \\
\text { - To know about the students' } \\
\text { psychological problems in } \\
\text { speaking } \\
\text { - To know about the efforts to } \\
\text { overcome the students' } \\
\text { psychological problems in } \\
\text { speaking. }\end{array}$ \\
\hline
\end{tabular}

In analyzing the data, the researcher analyzes the data in observation and interview qualitatively. According to Miles and Huberman in Sugiyono (2016:246) explains that there are three steps of data analysis: data reduction, data display, and conclusion drawing and verification.

\section{FINDINGS AND DISCUSSION}

\section{The students' Psychological Problems in}

\section{Speaking}

Based on the research, when the students spoke in front of the class, they were found many problems. This was also supported by the result of observation and interview. The results are as follows:

\section{Anxiety}

The researcher found that the students were felt anxiety when they were speaking. Before the students presented the speak, the students looked worried, anxious, and discomfort. Their attitude when speaking was looking awkward. The students looked fear and afraid of being bullied by their friends. The students did not dare to look at their friends. The feeling of nervousness and anxiety of students influenced their speaking performance. This was supported by the interview with the student:

[MA] "when I went forward to speak, my first feeling that I feel is nervous, miss. So, my mind got blank"

(Interview, 27/02/20) 


\section{Shyness}

When another student went forward, the student said to the researcher that she was shy when speaking and their friends were looking at her. When she was speaking, her speaking performance is good enough. She spoke fluently. But, she was felt shy and unconfident when speaking in front of their friends. She also spoke in a low voice. So, all of her friends could not be heard what she said.

The data interview from the teacher also said that the students also felt shy when practice speaking. The teacher explained that the students felt shy when speaking in front of the class because the students were shy to be seen by their friends.

$[P]$ "then, the students feel shy when speaking in front of the class and being attention by their friends. (Interview, (05/03/20)

Based on the data of the interview from the other student, the student thought that English is difficult and he cannot master it. It caused the student felt ashamed and shy if he did something wrong when performing his speech in front of his friends. The student thought that he will be laughed at by his friend.

$$
\begin{aligned}
& {[N C] \text { "I feel shy when my friends }} \\
& \text { are laughing at me." }
\end{aligned}
$$

\section{Fear of making mistakes}

From the observation, the researcher could see that the students were fear of making mistakes. When the students went forward. Their voice could be heard clearly by the researcher, but in some cases, they lowered their voices because they were not sure of what they were saying. They were afraid of making mistakes. They were also afraid of being laughed by their friends when making mistakes in speaking English. They prefered to lower their voice, so that, their mistakes were not known or heard by their friends. It because when the students making mistakes in speaking performance, their friends will laugh, bully, and shout at them. So, when they were making 
mistakes, the students will lower their voice to avoid being heard by their friends.

The student said that he was fear of making mistakes. The student said that he will felt shy when he was making mistakes. The student said that he had selfconfidence when he went forward, but if he made mistakes he will felt ashamed, shy and became unfocused. He said that their friends will laugh and he will be a joke for the other friends.

\section{[MA]"because I am afraid of making mistakes." (Interview,06/03/20)}

\section{Lack of confidence}

Self-confident is important to build speaking performance. But, one of the problems that students usually faced is lack of confidence that hinder the students to practice their speaking. The students' also unconfident to speak using English. They were looking doubt and unconfident when speak. Some students had a good performance in English. But, they said that they were feeling unconfident when speaking in front of their classmates.
Based on the interview with the teacher, the researcher knows that the students have lack of confidence when speaking English in front of the class. This supported by the teacher statement:

[NU] "many students feel unconfident”" (Interview, 06/03/20)

It is also supported by the interview that the researcher did with the student. According to the student statement, the cause of students' lack of confidence was came from the internal of the students. The student said that she was felt unconfident when speaking. The student said that she was felt unconfident because she was not fluent in speaking English.

[LNMS] 'I am not confident miss, because I was not fluent in speaking English"

(Interview,06/03/2020)

Besides, the internal cause of the lack of confidence, the students also have the external cause of their lack of confidence. The cause was came from the environment of the students or from the criticism of her friends. The student has 
good performance in English. But, she was afraid of being judge or bully that she was an arrogant student when speak using English in the class.

\section{The Efforts to overcome the Students'} Psychological Problems in Speaking

To know about the efforts to overcome the psychological problems in speaking, the researcher conducted interview with English teachers. According to the opinions of the teachers, these were the efforts to overcome the psychological problems faced by the students in speaking.

\section{Increase self-confidence}

Based on the interview with the teacher, the teacher said that speaking needs self-confidence. If the students are confident to speak, that can increase their speaking and decrease their problems. So, the teacher must embed self-confidence to the students. The teacher also added that students should not be afraid of made mistakes.
[P]"because speaking needs selfconfidence, so speaking in English is needed self-confidence. This should embed to the students" (Interview, 05/03/20)

This was related with Brown (2000:145) that no successful cognitive or affective activity can be carried out without some degree of self-esteem, selfconfidence, knowledge of yourself, and belief in your capabilities for that activity.

\section{Mastering vocabulary}

Another effort is the student should mastering much vocabulary. Many students were lack of vocabulary mastering. So, when the students have much vocabulary, the students will dare to speak in front of the class and it will decrease their problems. The students should memorize and master much vocabulary.

$$
\begin{aligned}
& \text { [NU]"first, the students should } \\
& \text { memorize or master much } \\
& \text { vocabulary" (Interview,06/03/20) } \\
& \text { This is in line with Swary } \\
& \text { mastering English vocabulary was the }
\end{aligned}
$$


most important component, so to solve that problems, all of the students have to increase their vocabulary knowledge first.

\section{Practice}

Another effort is practice speaking English. The student should practice more to speak in English, both inside and outside the class and the school. This was supported by the interview with the teacher.

[NU]"the students should practice more, both inside and outside the school." (interview,06/03/20) $[P]$ " then, the students should practice more to speaking in English." (interview, 05/03/20)

This is related with Swary (2014:50) said that language was a practice. Swary (2014:50) added that the students should practice their English not only in the class activity but also in the out of the class activity.

\section{Giving motivation}

The other effort is giving motivation. The teacher should appreciate and motivate the students when the students learned or tried to speak in
English. Although, the students had many mistakes or not good enough, the students must be appreciated so that the student will enthusiasm in learning. The teacher can give appreciation and motivation to the students, so that can build students motivation in learning English and that can decrease their problems.

$[P]$ "when the students speaking, although they have many mistakes or not good enough, the students must be appreciated so that the student will enthusiasm in learning." (Interview, 05/03/20) $[\mathrm{NU}]$ "and giving motivation." (Interview, 06/03/20)

This is supported by This was also supported with the theory by Swary (2014:52) that if the students had the big motivation to learn speaking English, to speak up in front of their friends automatically they would be always follow everything which the teacher words in order to make them increase their ability in speaking English. So, the willingness to speak of students are influenced by their ability to speak. 


\section{Habitual}

The other effort is habitual.

According to the teacher opinions, the teachers said that students should have the habitual in using English. The teachers added that the students also accustomed themselves to speak in English, either with the teachers or their friends.

[P] "habitual, the students should accustom themselves to speaking English, either with the teacher or with their friends." (Interview, 05/03/20)

[NU]"then, accustom themselves to use English."

(Interview,06/03/20)

\section{CONCLUSION}

Based on the aim of the study, it can be concluded that students' faced some psychological problems such as anxiety, shyness, fear of making mistakes and lack of confidence. Those psychological problems can hinder the students to improve their speaking in English class. Then, the efforts to overcome the students' psychological problems are increase self-confidence, mastering a lot of vocabulary, more practice in speaking English, giving motivation and whether the students and teachers should have the habitual or accustomed in using and speak English.

\section{REFERENCES}

Ariyanti. (2016). Psychological Factors Affecting EFL Students Speaking Performance. Asian TEFL.

Ary, D. (2010). Introduction to Research in Education (8th Edition). Wadsworth: Chengage Learning.

Brown, H. D. (2000). Primciple of Language Learning and Teaching , Fourth Edition. New York: Longman.

Brown, H. D. (2001). Teaching By Principles, An International Approach to Language Pedagogy. New York: Longman.

He, L. (2015). Exploring Affective Factors Influencing Spoken English Teaching in College . International Conference on Education, Language, Art and Intercultural Communication (ICELAIC).

Juhana. (2012). Psychological Factors That Hinder Students from Speaking in English Class (A Case Study in a Senior High School in South Tangerang, Banten, Indonesia). The English Department, Indonesia Open University- Journal of Education and Practice, Vol 3, No. 12, 2012. 
Kayi, H. (2006). Teaching Speaking: Activities to Promote Speaking in a Second Language.

Madaci, L. (2018). The Effect of Fear of Negative Evaluation EFL Learners' Oral Performance.
Munir, M. M. (2018). Psychological Factors that Hinder Students in Speaking Skill in the Classroom (A Case Study of the Sevent Grade Students of SMP N 2 Banyubiru in the Academic Year of 2017/2018). 